\title{
EFEKTIVITAS MEDIA LEAFLET DAN TABLET FE PADA IBU HAMIL TERHADAP ANEMIA
}

\author{
Eline Charla S. Bingan'1) \\ ${ }^{1}$ Jurusan Kebidanan, Poltekkes Kemenkes Palangka Raya, Jl. G. Obos No. 30/32 \\ Palangka Raya, 73111 \\ e-mail : elinecarlabingan@gmail.com
}

\begin{abstract}
Anemia of pregnancy is called "potential danger to mother and child". The group at risk for anemia is pregnant women. Risk factors for anemia in pregnancy are low iron intake and consumption of iron tablets. This researchTo determine the effectiveness of media leaflets and tablet Fe in pregnant women against the incidence of anemia in Primary Health Care (PHC) Bukit Hindu. This methods of research is Quasi Experiment approach Non-randomized control group Pretest - Post test Design. The sample of in this study were 30 pregnant women in the PHC Bukit Hindu Working Area. Analyze data using the Independent Samples t-Test. Based on the results of the analysis, the experimental group obtained a Sig (2-tailed) value of $0,000<0,05$. While in the control group, the Sig (2-tailed) value was $0.002<0.05$. So, the experimental group was more effective in increasing Hb levels of pregnant women than in the control group. There is a difference in the average effectiveness of leaflet and tablet fe media for pregnant women on the incidence of anemia. It is recommended for pregnant women to consume 90 fe tablets given by health institutions to reduce the incidence of anemia.
\end{abstract}

Keywords: leaflets, fe tablet, pregnant women, anemia

\begin{abstract}
Abstrak
Anemia kehamilan disebut "potential danger to mother and child". Kelompok yang berisiko menderita anemia adalah ibu hamil. Faktor resiko terjadinya anemia dalam kehamilan adalah rendahnya asupan zat besi dan konsumsi tablet zat besi. Penelitian ini mengetahui efektivitas media leaflet dan tablet fe pada ibu hamil terhadap kejadian anemia di UPT Puskesmas Bukit Hindu Kota Palangka Raya Jenis penelitian yang digunakan adalah penelitian eksperimen semu (Quasi Experiment) dengan pendekatan Non randomized control Grup Pre test - Post test Design. Jumlah sampel sebanyak 30 orang ibu hamil yang ada di Wilayah Kerja Puskesmas Bukit Hindu. Analisa data menggunakan uji Independent Samples T Test. Berdasarkan hasil analisis, pada kelompok eksperimen diperoleh nilai Sig (2-tailed) sebesar 0,000< 0,05. Sedangkan pada kelompok kontrol diperoleh nilai Sig (2-tailed) sebesar 0,002 < 0,05. Maka, kelompok eksperimen lebih efektif meningkatkan kadar $\mathrm{Hb}$ ibu hamil dibandingkan kelompok kontrol. Ada perbedaan rata-rata efektivitas media leaflet dan tablet fe pada ibu hamil terhadap angka kejadian anemia. Disarankan bagi ibu hamil untuk mengkonsumsi 90 tablet fe yang diberikan oleh intansi kesehatan untuk mengurangi angka kejadian anemia.
\end{abstract}

Kata Kunci: leaflet, tablet fe, ibu hamil, anemia

\section{PENDAHULUAN}

$$
\text { Angka Kematian Ibu (AKI) }
$$

menjadi salah satu indikator penting

dalam menentukan derajat kesehatan masyarakat. Kematian ibu dapat disebabkan oleh penyebab obstetrik langsung dan tidak langsung. Salah satu penyebab tidak langsung kematian ibu adalah penyakit yang mungkin telah terjadi sebelum kehamilan dan diperburuk oleh kehamilan itu sendiri, diantaranya adalah anemia. Di 
Indonesia anemia terjadi pada 1 dari 3 ibu hamil.

Penanggulangan anemia dilaksanakan dengan pemberian tablet besi (Fe) sebanyak 90 tablet kepada setiap ibu hamil. Cakupan tablet Fe pada tahun 2017 di Kota Palangkaraya adalah Fe1 sebesar $2.406(41,46 \%)$ dan Fe3 sebesar $2.056 \quad(35,43 \%)$, mengalami penurunan jika dibandingkan tahun 2016 adalah Fe 1 $5.045 \quad(86,15 \%) \quad$ dan $\quad \mathrm{Fe} 3 \quad 4.428$ $(75,61 \%)$. (Profil Kesehatan Kota Palangka Raya 2017).

Faktor resiko terjadinya anemia dalam kehamilan adalah rendahnya asupan zat besi, absorpsi zat besi rendah, yang dapat disebabkan dari konsumsi makanan yang mengandung fitat dan fenol serta rendahnya konsumsi tablet zat besi (Aditianti, dkk, 2015).

Salah satu faktor yang dapat mengurangi jumlah anemia adalah kepatuhan terhadap konsumsi tablet tambah darah. Pengetahuan dan kesadaran ataupun sikap ibu akan pentingnya mengkonsumsi tablet tambah darah selama kehamilan dapat ditingkatkan dengan dilakukan tindakan agar dapat menambah pemahaman ibu hamil diantaranya yaitu dengan melakukan konseling pada ibu hamil. Untuk membantu keberhasilan konseling maka dibutuhkan alat bantu (media). Penggunaan media dalam pembelajaran sangatlah penting karena dapat memudahkan dalam menerima materi, tetapi dalam menggunakan media, kita harus mengetahui karakteristik tersebut sebelum dipilih dan digunakan dalam suatu konseling agar tujuan yang diharapkan dapat tercapai. Media leaflet merupakan salah satu media dengan lembaran lipat yang memiliki banyak informasi tentang kesehatan dapat digunakan untuk membantu berjalannya konseling kesehatan.

\section{METODE PENELITIAN}

Jenis penelitian yang digunakan adalah penelitian eksperimen semu (Quasi Experiment). Penelitian ini menggunakan pendekatan Non randomized control Grup Pre test Post test Design.

Observasi dilakukan sebanyak 2 kali, yaitu pada awal (Pretest), dan akhir kegiatan (Posttest) yang dilakukan setelah Pretest. Pretest dan Posttest dilakukan untuk menguji adanya perubahan-perubahan yang terjadi setelah adanya penyuluhan (Notoatmodjo, 2010). 
Jumlah sampel dalam penelitian ini adalah 30 orang dan subjek penelitian ini adalah ibu hamil yang ada di Wilayah Kerja Puskesmas Bukit Hindu. Sampel dibagi menjadi 2 kelompok yaitu kelompok eksperimen dan kelompok kontrol. Kelompok eksperimen adalah kelompok yang diberikan leaflet dan tablet fe sedangkan

kelompok kontrol adalah kelompok yang hanya mendapatkan tablet fe. Untuk cara penarikan sampel adalah pemilihan dengan non probability sampling.

\section{A. HASIL DAN PEMBAHASAN}

\section{Hasil Univariat}

Tabel 4.1 Distribusi Frekuensi Kadar Hb Ibu Hamil Sebelum dan Sesudah Diberikan Tablet Fe pada kelompok Eksperimen

\begin{tabular}{cccc}
\hline Kadar Hb & Mean $($ gr/dl) & SD & Min-Max \\
\hline Pretest & 10,360 & 0,4687 & $9,7-11,5$ \\
\hline Postest & 10,747 & 0,2642 & $10,2-11,1$ \\
\hline
\end{tabular}

Dari tabel 4.1 didapatkan bahwa hasil pretest memiliki rata-rata 10,360 gr/dl, standar deviasi 0,4687, hasil kadar $\mathrm{Hb}$ terendah adalah 9,7 gr/dl dan hasil kadar $\mathrm{Hb}$ tertinggi adalah 11,5 gr/dl.
Sedangkan pada postest didapatkan bahwa mean 10,747 gr/dl, standar deviasi 0,2642, minimal dan maksimal adalah 10,2 gr/dl dan 11,1 gr/dl.

Tabel 4.2 Distribusi Frekuensi Kadar Hb Ibu Hamil Sebelum dan Sesudah Diberikan Tablet Fe pada kelompok Kontrol

\begin{tabular}{cccc}
\hline Kadar Hb & Mean $(\mathbf{g r} / \mathbf{d l})$ & SD & Min-Max \\
\hline Pretest & 10,460 & 0,3562 & $9,9-11,1$ \\
\hline Postest & 10,707 & 0,3011 & $10,3-11,5$ \\
\hline
\end{tabular}

Dari tabel 4.2 didapatkan bahwa hasil pretest memiliki rata-rata 10,460 $\mathrm{gr} / \mathrm{dl}$, standar deviasi $0,3562 \mathrm{ml}$, hasil kadar $\mathrm{Hb}$ terendah adalah 9,9 gr/dl dan hasil kadar $\mathrm{Hb}$ tertinggi adalah 11,1 gr/dl. Sedangkan pada postest didapatkan bahwa mean 10,707 gr/dl, standar deviasi 0,3011, minimal dan maksimal adalah 10,3 gr/dl dan 11,5 gr/dl. 
Tabel 4.3 Distribusi Frekuensi Kepatuhan Ibu Hamil dalam Konsumsi Tablet Fe Berdasarkan Usia dan Pendidikan (Variabel Perancu) di UPT Puskesmas Bukit Hindu (n=30)

\begin{tabular}{|c|c|c|c|c|c|c|}
\hline \multirow{2}{*}{ Karakteristik } & \multicolumn{2}{|c|}{ Patuh } & \multicolumn{2}{|c|}{ Kurang Patuh } & \multicolumn{2}{|c|}{ TOTAL } \\
\hline & $\mathbf{N}$ & $\%$ & $\mathbf{n}$ & $\%$ & n & $\%$ \\
\hline \multicolumn{7}{|l|}{ Usia } \\
\hline$<20$ tahun & 1 & 3,3 & 0 & 0 & 1 & 3,3 \\
\hline 20-35 tahun & 12 & 40 & 11 & 36,7 & 23 & 76,7 \\
\hline$>35$ tahun & 4 & 13,3 & 2 & 6,7 & 6 & 20 \\
\hline \multicolumn{7}{|l|}{ Pendidikan } \\
\hline PT & 4 & 13,3 & 3 & 10 & 7 & 23,3 \\
\hline SMA & 13 & 43,3 & 8 & 26,8 & 21 & 70,1 \\
\hline SMP & 0 & 0 & 1 & 3,3 & 1 & 3,3 \\
\hline SD & 0 & 0 & 1 & 3,3 & 1 & 3,3 \\
\hline
\end{tabular}

Berdasarkan tabel 4.3 dapat diketahui bahwa dari 30 ibu hamil yang memiliki usia $<20$ tahun dan patuh mengkonsumsi tablet fe adalah sebanyak 1 orang $(3,3 \%)$, ibu hamil usia 20 - 35 tahun dan patuh mengkonsumsi tablet fe sebanyak 12 orang (40\%) sedangkan yang kurang patuh mengkonsumsi tablet fe sebanyak 11 orang $(36,7 \%)$ dan usia $>35$ tahun dan patuh mengkonsumsi tablet fe sebanyak 4 orang $(13,3 \%)$ sedangkan yang kurang patuh mengkonsumsi tablet fe sebanyak 2 orang $(6,7 \%)$.

Berdasarkan karakteristik pendidikan, diketahui bahwa jumlah ibu hamil lulusan PT dan patuh mengkonsumsi tablet fe yaitu 4 orang $(13,3 \%)$ sedangkan yang kurang patuh mengkonsumsi tablet fe sebanyak 3 orang (10\%), ibu hamil tamatan SMA dan patuh mengkonsumsi tablet fe lebih banyak yaitu 13 orang (43,3\%) sedangkan yang kurang patuh mengkonsumsi tablet fe sebanyak 8 orang $(26,8 \%)$, ibu hamil tamatan SMP dan kurang patuh mengkonsumsi tablet fe sebanyak 1 orang (3,3\%), dan tamatan SD dan kurang patuh mengkonsumsi tablet fe sebanyak 1 orang $(3,3 \%)$.

\section{Hasil Bivariat}

Penelitian ini dilakukan untuk mengetahui perbedaan kadar $\mathrm{Hb}$ sebelum dan sesudah minum tablet $\mathrm{Fe}$. Sampel yang digunakan sebanyak 30 ibu hamil. Kemudian dilakukan pengujian dengan menggunakan uji Paired T Test. 


\begin{tabular}{|c|c|c|c|c|c|c|c|}
\hline Kadar Hb & Mean & SD & SE & Lower & Upper & Min-Max & $\begin{array}{c}P- \\
\text { value }\end{array}$ \\
\hline Pretest & 10,360 & 0,4687 & \multirow{3}{*}{0,0768} & \multirow{3}{*}{$-0,5513$} & \multirow{3}{*}{$-2,2220$} & $9,7-11,5$ & \multirow{3}{*}{$\mathbf{0 , 0 0 0}$} \\
\hline Postest & 10,747 & 0,2642 & & & & $10,2-11,1$ & \\
\hline Perbedaan & $-0,3867$ & 0,2973 & & & & & \\
\hline
\end{tabular}

Berdasarkan hasil uji statistik pada tabel 4.4 menggunakan uji paired test terdapat perbedaan rata-rata kadar $\mathrm{Hb}$ pretest sebesar $-0,3867 \mathrm{gr} / \mathrm{dl}$. Nilai lower dan upper adalah -0,5513 dan 2,2220. Pada hasil pretest minimal dan maksimal adalah 9,7 gr/dl dan 11,5 gr/dl. Sedangkan pada postest minimal dan maksimal adalah 10,2 gr/dl dan $11,1 \mathrm{gr} / \mathrm{dl}$. Dapat diketahui bahwa $p$ value tersebut lebih kecil dari $\alpha(0,05)$ yaitu sebesar 0,000, sehingga dapat disimpulkan bahwa media leaflet dan tablet fe efektif terhadap peningkatan kadar $\mathrm{Hb}$ pada ibu hamil.

Tabel 4.5 Uji Paired T Test Perbedaan Rata-Rata Kadar Hb Ibu Hamil Sebelum dan Sesudah Diberikan Tablet Fe pada kelompok Kontrol

\begin{tabular}{|c|c|c|c|c|c|c|c|}
\hline Kadar Hb & Mean & SD & SE & Lower & Upper & Min-Max & $\begin{array}{c}P- \\
\text { value }\end{array}$ \\
\hline Pretest & 10,460 & 0,3562 & \multirow{3}{*}{0,0654} & \multirow{3}{*}{$-0,3869$} & \multirow{3}{*}{$-0,1065$} & $9,9-11,1$ & \multirow{3}{*}{0,002} \\
\hline Postest & 10,707 & 0,3011 & & & & $10,3-11,5$ & \\
\hline Perbedaan & $-0,2467$ & 0,2532 & & & & & \\
\hline
\end{tabular}

Berdasarkan hasil uji statistik pada tabel 4.5 menggunakan uji paired test terdapat perbedaan rata-rata kadar $\mathrm{Hb}$ pretest sebesar $-0,2467$ gr/dl. Nilai lower dan upper adalah -0,3869 dan 0,1065. Pada hasil pretest minimal dan maksimal adalah 9,9 gr/dl dan 11,1 gr/dl. Sedangkan pada postest minimal dan maksimal adalah 10,3 gr/dl dan 11,5 gr/dl. Dapat diketahui bahwa $p$ - value tersebut lebih kecil dari $\alpha(0,05)$ yaitu sebesar 0,002, sehingga dapat disimpulkan bahwa tablet fe efektif terhadap peningkatan kadar $\mathrm{Hb}$ pada ibu hamil.

\section{Pembahasan}

\section{a. Pembahasan Usia dan Pendidikan}

Pada penelitian ini usia ibu hamil yang menjadi sampel penelitian 
kebanyakan berusia 20 - 35 tahun yaitu sebanyak 23 ibu hamil $(76,7 \%)$ sedangkan yang berusia kurang dari 20 tahun sebanyak 1 ibu hamil (3,3\%). Dan ibu hamil yang patuh mengkonsumsi tablet fe lebih banyak pada rentang usia 20-35 tahun yaitu sebanyak 12 orang (40\%). Hal ini berarti tingkat kesadaran ibu untuk menjalani kehamilan pada usia 20 - 35 tahun sudah baik guna menghindari resiko kehamilan dan persalinan karena faktor usia.

Ibu hamil dengan usia $<20$ tahun yang mengkonsumsi tablet tambah darah rutin setiap hari hanya $3,3 \%$, ibu hamil usia 20 - 35 tahun mengkonsumsi tablet tambah darah secara rutin setiap hari sebesar $40 \%$, ibu hamil usia > 35 tahun yang mengkonsumsi tablet tambah darah rutin sebesar 13,3\%, sedangkan ibu hamil tidak mengkonsumsi tablet secara rutin dominan pada usia 20-35 tahun sebesar $36,7 \%$.

Pada ibu hamil di UPT Puskesmas Bukit Hindu, usia bukanlah variabel yang berpengaruh terhadap konsumsi tablet tambah darah. Ibu hamil berusia lebih tua belum tentu memiliki tingkat konsumsi tablet tambah darah tinggi, namun sebaliknya ibu hamil berusia lebih muda juga belum tentu memiliki tingkat konsumsi tablet tambah darah rendah. Ibu hamil tidak mengetahui kelompok usia berisiko dan tidak berisiko untuk hamil, sehingga tidak mengetahui bagaimana kebutuhan konsumsi tablet, khususnya pada ibu hamil pada kelompok usia berisiko. Ibu hamil menganggap usia dan kehamilan tidak berkaitan, padahal ketika ibu hamil berada usia risiko tinggi kemungkinan adanya komplikasi kehamilan dan akan menimbulkan risiko yang lebih besar.

Tingkat pendidikan ibu hamil yang datang memeriksakan kehamilannya bervariasi mulai dari yang tamat SD sampai sarjana (S1). Dimana pada tabel 4.3 menggambarkan jumlah terbanyak tingkat pendidikan ibu hamil adalah SMA yaitu sebanyak 21 ibu hamil atau sebanyak 70\%. Dan ibu hamil yang patuh mengkonsumsi tablet fe paling banyak pada ibu dengan pendidikan SMA.

Pengalaman yang banyak pada ibu hamil, memiliki tingkat kematangan jiwa serta emosi dalam mengambil suatu keputusan dalam mengkonsumsi tablet setiap hari secara rutin. Pendidikan seseorang dapat mempengaruhi pemahaman atas suatu prosedur, maka semakin tinggi 
pendidikan ibu, makin semakin banyak informasi dan pengetahuan dimiliki sehingga kepatuhan semakin tinggi.

Tingkat konsumsi tablet pada ibu hamil dipengaruhi pengetahuan mengenai manfaat serta dampak yang ditimbulkan dari masalah anemia. Pengetahuan memiliki peran penting dalam menentukan tingkat konsumsi tablet pada ibu hamil karena akan berpengaruh langsung pada sikap ibu hamil untuk mengonsumsi tablet setiap hari. Pengetahuan kurang mengenai masalah anemia pada ibu hamil akan berpengaruh terhadap perilaku kesehatan pada saat hamil yang mengakibatkan kurang optimal untuk melakukan perilaku pencegahan terkena masalah anemia kehamilan.

Pada penelitian ini, rata-rata kadar $\mathrm{Hb}$ ibu hamil kelompok eksperimen sebelum perlakuan adalah 10,360 dan setelah perlakuan adalah 10,747. Artinya, kadar $\mathrm{Hb}$ ibu hamil kelompok eksperimen mengalami kenaikan ratarata sebesar 0,38 gr/dl, sedangkan pada kelompok kontrol rata-rata kadar $\mathrm{Hb}$ ibu hamil sebelum perlakuan adalah 10,460 dan setelah perlakuan adalah 10,707. Artinya, kadar $\mathrm{Hb}$ ibu hamil kelompok kontrol mengalami kenaikan rata-rata kadar $\mathrm{Hb}$ sebesar 0,25 gr/dl setelah diberikan perlakuan.

Berdasarkan hasil analisis pada kelompok eksperimen diperoleh nilai Sig (2-tailed) sebesar $0,000<0,05$, maka dapat disimpulkan ada perbedaan rata-rata angka kejadian anemia dari efektivitas media leaflet dan tablet $\mathrm{Fe}$ pada ibu hamil. Sedangkan hasil analisis pada kelompok kontrol diperoleh nilai Sig (2-tailed) sebesar 0,002 $<0,05$, maka dapat disimpulkan ada perbedaan rata-rata angka kejadian anemia dari efektivitas tablet Fe pada ibu hamil.

Dari hasil analisis dapat disimpulkan bahwa pada kelompok eksperimen lebih efektif meningkatkan kadar $\mathrm{Hb}$ ibu hamil dibandingkan kelompok kontrol. Pada penelitian ini dilakukan dengan menggunakan media leaflet pada kelompok eksperimen, sedangkan pada kelompok kontrol tidak diberikan media leaflet. Media leaflet dapat mempengaruhi pengetahuan dan berujung kepada sikap ibu hamil terhadap konsumsi tablet tambah darah. Peningkatan informasi yang diberikan kepada ibu hamil akan berdampak pada peningkatan pengetahuan tentang tablet tambah darah. Setelah memahami tablet tambah darah, maka ibu akan melakukan evaluasi pada perilaku 
dalam mengkonsumsi tablet tambah darah. Ketika ibu merasa bahwa perilaku kurang tepat, maka ibu akan memilih perilaku-perilaku yang lebih baik, sehingga meningkatkan sikap terhadap konsumsi tablet tambah darah.

Faktor utama yang mempengaruhi sikap ibu hamil dalam penelitian ini adalah pengetahuan, dimana pengetahuan yang meningkat karena adanya edukasi yang diberikan. Pengetahuan yang meningkat akan membuat ibu lebih paham tentang manfaat dari mengkonsumsi tablet tambah darah. Akan tetapi sikap yang baik tidak sepenuhnya bisa mengubah ibu hamil menjadi patuh. Sejalan dengan penelitian yang dilakukan oleh Robiatul Adawiyani (2013), pengaruh pemberian booklet anemia terhadap Pengetahuan, kepatuhan minum tablet tambah darah dan kadar hemoglobin ibu hamil, menunjukkan adanya perbedaan pengetahuan yang bermakna pada kelompok kontrol dan kelompok uji dengan $\mathrm{P}$ value $=0,000$. Hal ini menunjukkan bahwa metode edukasi berupa pemberian booklet anemia dapat memberi peningkatan pengetahuan pada ibu hamil.

Menurut Prawirohardjo (2010) anemia dalam kehamilan yang paling sering dijumpai adalah anemia gizi besi, hal ini disebabkan kurangnya asupan zat besi dalam makanan karena gangguan reabsorbsi, gangguan penggunaan atau perdarahan. Frekuensi anemia dalam kehamilan di dunia cukup tinggi berkisar antara 10\% dan 20\%. Seorang wanita hamil yang memiliki kadar Hemoglobin $(\mathrm{Hb})$ kurang dari 10gr\% disebut menderita anemia dalam kehamilan. Anemia pada kehamilan atau kekurangan kadar hemoglobin dalam darah dapat menyebabkan komplikasi yang lebih serius bagi ibu baik dalam kehamilan, persalinan dan nifas yaitu dapat mengakibatkan abortus, partus prematurus, dan partus lama. Beberapa faktor penyebab anemia pada ibu hamil antara lain adalah dalam kenyataan tidak semua ibu hamil yang mendapat tablet zat besi meminumnya secara rutin, hal ini bisa disebabkan karena faktor ketidaktahuan pentingnya tablet zat besi dan penyerapan/respon tubuh terhadap tablet besi kurang baik sehingga tidak terjadi peningkatan kadar Hemoglobin sesuai dengan yang diharapkan.

Pada penelitian Djamilus dan Herlina tahun 2008 menyatakan bahwa semakin ibu hamil minum tablet $\mathrm{Fe}$ semakin rendah kejadian anemia pada 
ibu hamil. Ibu hamil yang tidak rutin mengkonsumsi tablet $\mathrm{Fe}$ mempunyai risiko 2,429 kali lebih besar untuk mengalami anemia dibanding yang rutin konsumsi tablet.

Anemia pada ibu hamil disebabkan karena ketidakpatuhan ibu hamil mengkonsumsi tablet Fe. Ketidakpatuhan ibu hamil dalam mengkonsumsi tablet Fe dipengaruhi oleh peran bidan yang masih kurang terhadap konseling pentingnya mengkonsumsi tablet $\mathrm{Fe}$ selama kehamilan. Berdasarkan penelitian Amaliana (2015) peran bidan yang kurang mempengaruhi ketidakpatuhan ibu hamil dalam mengkonsumsi tablet Fe karena bidan merupakan tenaga kesehatan pertama yang langsung berhubungan dengan ibu hamil, sehingga patuh atau tidak patuhnya ibu hamil dalam mengkonsumsi tablet $\mathrm{Fe}$ memang sangat dipengaruhi oleh bidan.

Ketidakpatuhan ibu hamil dalam mengkonsumsi tablet $\mathrm{Fe}$ memberikan peluang lebih besar untuk terkena anemia. Hal ini sejalan dengan penelitian Gebre (2015) ibu yang patuh mengkonsumsi tablet $\mathrm{Fe}$ tidak mengalami anemia dan janin sejahtera, tetapi jika ibu hamil tidak patuh mengkonsumsi tablet $\mathrm{Fe}$ akan beresiko mengalami anemia lebih tinggi.

Hal ini sejalan dengan penelitian Wahidah Adilestari Tahun 2017 "Hubungan Kepatuhan Ibu Hamil Mengkonsumsi Tablet $\mathrm{Fe}$ Dengan Kejadian Anemia Di Puskesmas Mantrijeron Yogyakarta" Ada hubungan antara kepatuhan ibu hamil mengkonsumsi tablet $\mathrm{Fe}$ dengan kejadian anemia. Hal ini diperoleh dari hasil uji statistik bahwa nilai significancy p sebesar 0,004 yang berarti $\mathrm{Ha}$ diterima dan $\mathrm{H} 0$ ditolak dan nilai koefisien kontingensi 0,339. Diharapkan ibu hamil patuh mengkonsumsi tablet $\mathrm{Fe}$, melihat pentingnya mengkonsumsi tablet $\mathrm{Fe}$ selama kehamilan serta akibat yang dapat ditimbulkan bila tidak dikonsumsi secara tepat.

Hasil dari penelitian ini sesuai dengan hipotesis yang disusun dalam penelitian yaitu ada perbedaan rata-rata efektivitas media leaflet dan tablet fe pada ibu hamil terhadap angka kejadian anemia. Kejadian anemia dapat dihindari dengan patuh mengkonsusmsi tablet Fe sesuai dengan aturan, selain itu juga bisa didukung dengan pemberian media leaflet sebagai pembelajaran dan pengetahuan ibu tentang anemia dan 
menghindari faktor-faktor yang dapat menjadikan risiko ibu hamil untuk terkena anemia.

\section{SIMPULAN}

Berdasarkan hasil penelitian yang telah dilakukan di UPT Puskesmas Bukit Hindu Palangka Raya tentang efektivitas media leaflet dan tablet fe pada ibu hamil terhadap angka kejadian anemia maka dapat disimpulkan ada perbedaan rata-rata efektivitas media leaflet dan tablet fe pada ibu hamil terhadap angka kejadian anemia.

Hal ini diperoleh dari hasil uji statistik nilai Sig (2-tailed) sebesar $0,000<0,05$, maka dapat disimpulkan ada perbedaan rata-rata angka kejadian anemia dari efektivitas media leaflet dan tablet Fe pada ibu hamil.

\section{DAFTAR PUSTAKA}

Afnita, D. 2004. Hubungan Perilaku Ibu Hamil dan Motivasi Petugas Kesehatan Terhadap Kepatuhan dalam Mengkonsumsi Tablet Zat Besi pada Ibu Hamil di Rumah Sakit Ibu dan Anak Badrul Aini Medan. [Skripsi] Mahasiswa FKM Universitas Sumatera Utara.

Dinas Kesehatan Kab/Kota Palangka Raya. 2017. Profil Kesehatan
Kab/Kota Palangka Raya. Palangka Raya: Dinkes. Kementerian Kesehatan RI. 2010. Profil Kesehatan Naional Indonesia 2017. Jakarta: Depkes RI.

Hermiko, A.K. 2010. Apa beda Pamflet dan Leaflet?. Jakarta. Diakses tanggal 30 Oktober 2018 dari http://www.KharismaBintang.net.

Hunter, Pizzolongo, Peter J dan, Amy. 2011. I Am Safe and Secure:Promoting Resilience in Young Children.YC Young Children Vol. 66 Edisi 2.Washington: National Associatiom for the Education of Young Children.

Kartikasari, Nur Dewi. 2010. Hubungan Antara Pengetahuan Dan Sikap Tentang Anemia Dengan Keteraturan Mengkonsumsi Fe Pada Ibu Hamil Di Bps Sri Lumintu Surakarta. Jurnal Kedokteran. Hal 1Hal 64.

Notoatmodjo. S. 2010. Metode Penelitian Kesehatan. Jakarta. Rineka Cipta.

Prawirohardjo. 2007. Ilmu Kandungan. Jakarta: Yayasan Bina Pustaka Sarwono Prawirohardjo.

Viva. 2018. 1 dari 5 Orang Indonesia Derita Anemia. Diakses Pada Tanggal $23 \quad$ Oktober 2018 /https://www.viva.co.id/gayahidup/kesehatan-intim/1031041-1dari-5-orang indonesia-deritaanemia. 